\title{
PROCESSO DE EXTRAÇÃO DE ÓLEOS ESSENCIAIS DE PROTIUM HEPTAPHYLLUM (AUBL.) MARCHAND DO SUL DA BAHIA E A INVESTIGAÇÃO DO SEU EFEITO EM BIOENSAIOS VEGETAIS
}

\author{
AUTOR: ISABELE PEREIRA DE SOUSA \\ CO-AUTOR/ORIENTADOR: KHETRIN SILVA MACIEL
}

Resumo: O objetivo do projeto é o processo de extração de óleo essencial de Protium heptaphyllum (Aubl.). Marchand e a investigação do seu efeito em bioensaios vegetais. $O$ experimento de extração do óleo foi realizado no Laboratório de Ecotoxicologia da CEPLAC e para a extração do óleo essencial foi utilizada a técnica hidrodestilação em aparelhagem do tipo Clevenger. Para a extração do óleo, foram utilizados $50 \mathrm{~g}$ de resina de P. heptaphyllum, colocados em contato direto com $250 \mathrm{~mL}$ de água, durante 2 horas na temperatura de $80^{\circ} \mathrm{C}$. Para a realização dos bioensaios fitotóxicos foram utilizadas sementes de Lactuca sativa $\mathrm{L}$. além do controle negativo com água destilada, as sementes foram expostas às concentrações de 6,$25 ; 12,5 ; 25 ; 50$ e $100 \mathrm{~g} \mathrm{~L}-1$ do óleo preparado. Após a medição radicular $48 \mathrm{~h}$, 10 raízes de cada tratamento foram fixadas em metanol: ácido acético (3:1), e armazenadas a $-20^{\circ} \mathrm{C}$. Após $120 \mathrm{~h}$ ao tratamento de imersão das sementes no extrato produzido foi induzida ao processo de análise de divisão mitótico para identificar as células meristemáticas para localizar as fases das células. O resultado obtido no processo de extração dos óleos essenciais definiu o tempo para extração dos óleos, é satisfatório quando se é extraído em curto período de tempo, pois, o prazo extenso pode ocasionar as perdas significativas dos compostos químicos, além de ser muito tóxico e influencia no desenvolvimento das sementes de alface não ocorrendo germinação em nenhuma concentração de óleo.

Palavras-chave: Protium heptaphyllum (Aubl.). Marchand, extração de óleos essenciais. 